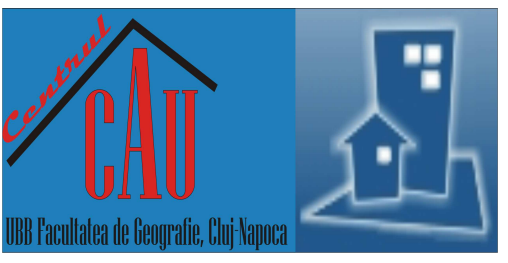

\title{
Student Mobility - Attractiveness and Premise of Improving the City Image. Case Study: Alexandru Ioan Cuza University of Iași
}

\author{
Cezara Ionela DULCE ${ }^{*}$, Ionel MUNTELE1 \\ * Corresponding author \\ 1“Al. I. Cuza” University, Faculty of Geography and Geology, Department of Geography, Iași, ROMANIA \\ $\triangle$ cezara.dulce@yahoo.com (1) https://orcid.org/oooo-0oo3-00oo-6122 \\ $\triangle$ imuntele@yahoo.fr (1) https://orcid.org/oooo-0oo2-3858-3286 \\ DOI: 10.24193/JSSPSI.2021.7.06 \\ https://doi.org/10.24193/JSSPSI.2021.7.06
}

K e y w o r d s: educational tourism, Erasmus+ internships, student mobility, flow distribution

\begin{abstract}
A B S T RA C T
Nowadays, brand image dominates almost any field of activity and becomes a source of power, being much more efficient than a word. Our article aims to analyse the evolution of Erasmus+ mobility at Alexandru Ioan Cuza University of Iași between 2013 and 2019 and to highlight, by the increasing attractiveness, the important role of these internships in the improvement of the city image. Regarding the methodology, our descriptive study was based on statistical information provided by the International Relations Office of the university. The purpose of the analysis was to identify the dynamics and distribution of student mobility flows, following the expressed trends. The results revealed a series of transformations: on the Outgoing component, numerous Romanian students chose for study notorious university centres in France, Spain, Italy, Germany and Poland and destinations in Greece, Italy or Iceland for an internship and, on the Incoming component, the increasing number of foreign students arrived from France, Spain, Poland and Portugal. Together with the traditional cultural assets of Iași, the increasing number of students involved in Erasmus+ internships can improve the city image as an attractive urban centre.
\end{abstract}

\section{INTRODUCTION}

Student mobility has increased in the context of globalization, the existence of inter-university exchange programs being an asset at the level of the European Union. Closely related to the cost of living and distance, these flows also depend significantly on the prestige of academic institutions (Rodriguez, Bustillo and Mariel, 2011). The reason of participating in these exchanges may be language learning and living in a different culture (Berna and Dürdane, 2014).

The impact of Erasmus-type programs is multifaceted, with some studies showing in the foreground the increase of relational potential, the increase of professional skills and the openness to interdisciplinarity (Mazilescu et al., 2016). Along with this, the urban image also has a determining role. Training students in various activities, along with the geographical quality of the place, is equally important from the perspective of the attractiveness of a university centre (Răcăşan et al., 2021). The urban image includes a complex set of concepts, ideas and impressions associated by a person with a particular object (Kotler, 1997) and is the result of the human ability to build mental representations of things, people, and organizations (Zară and Rus, 2000). In the last half century, the image of a place has gained a growing importance among researchers, politicians, practitioners, and media around the world (Paftală, 2013) and represents the set of beliefs formed by a 
buyer regarding a certain place (Kotler, Haider and Rein., 2001).

The benefits of promoting a positive image (implicitly attractive) for a specific target audience are globally recognized. Starting from the statement differentiate your self or die (Trout and Rivkin, 2006), the image becomes an advantage for the cities involved in the race for globalization. Today the biggest challenge they face is to identify and capitalize the components, attributes and practices that give them uniqueness in a coherent and sustainable development strategy.

An important element in building and improving the image of a city is the presence of important higher education institutions, a proof being numerous urban settlements recognized nationally and internationally as university centres. Some worldwide examples are Paris, London, Vienna, Berlin, Bologna, and Bucharest, Cluj-Napoca, Iași and Timișoara for
Romania. Another important element is tourism, heritage and tourist infrastructure becoming pull factors for the target audience and shaping the city image as a tourist destination. Placed between education and tourism, the educational tourism improves the image of a city as a major university centre through the important flows of students involved in international internships and the tourists arrived from the native countries of the students.

The city of Iași is a good example of a university centre with tradition. Among the elements that improve the image of the city as an attractive university centre are the presence of the first university in Romania (Alexandru Ioan Cuza University, 1860), the first printing house in the country (1508) and the highest number of students involved in Erasmus+ internships in the country. A detailed list of attributes is presented in Table 1.

Table 1. Iași - university centre: attributes (source: Alexandru Ioan Cuza University, 2020).

\begin{tabular}{|c|c|}
\hline Element & Details \\
\hline Vasile Alecsandri National Theatre & $\begin{array}{l}\text { The oldest national theatre and one of the most prestigious theatrical } \\
\text { institutions in Romania (1896) }\end{array}$ \\
\hline The obelisk with lions & The oldest monument in the country (1841) \\
\hline Anastasie Fătu Botanical Garden & The first botanical garden in Romania (1856) \\
\hline Natural History Museum & The first natural history museum in the country (1834) \\
\hline Ion Creangă Memorial House & The first literary memorial museum in Romania (1842) \\
\hline The first Jewish theatre in the world & The initiator is the Ukrainian writer Avram Goldfaden (1876) \\
\hline Great Synagogue & The oldest surviving synagogue in the country (1671) \\
\hline George Emil Palade & Nobel Prize winner (1974) \\
\hline Grigore Cobălcescu (1831-1892) & The author of the first Romanian work on geology (1862) \\
\hline Marta Trancu Rainer (1875-1950) & The first female surgeon in Romania \\
\hline Ella Negruzzi (1876-1948) & The first woman lawyer in the country \\
\hline $\begin{array}{l}\text { Society of Physicians and } \\
\text { Naturalists }\end{array}$ & The oldest Romanian scientific society (1833) \\
\hline $\begin{array}{l}\text { Eduard Gruber (1861-1896) } \\
\text { Physical chemistry }\end{array}$ & $\begin{array}{l}\text { The founder of the first laboratory of experimental psychology in the } \\
\text { country (1893) } \\
\text { The first course in physical chemistry (1921-1929) }\end{array}$ \\
\hline Electricity & The first electricity laboratory (1910) \\
\hline $\begin{array}{l}\text { The first printing house in the } \\
\text { country (The Miss, 1508) }\end{array}$ & Printed by the Serbian monk Macarie; displayed today at Dosoftei House \\
\hline
\end{tabular}

The general objective of our paper is to analyse the effects of student mobility in the university centre of Iași and the specific one is to analyse the particularities of these internships at Alexandru Ioan Cuza University, the existence of certain relationships between the university and partner countries and the impact of these relationships on the city image. In Iași, there are five public universities (Alexandru Ioan Cuza University, Ion Ionescu de la Brad University of Agricultural Sciences and Veterinary Medicine, Gheorghe Asachi Technical University, Grigore T. Popa University of
Medicine and Pharmacy and George Enescu National University of Arts) and a private one (Petre Andrei University). The city registered in 2019 about 50,000 students: 22,460 students (Alexandru Ioan Cuza University), 4,160 students (Ion Ionescu de la Brad University of Agricultural Sciences and Veterinary Medicine), 13,155 (Gheorghe Asachi Technical University), 9,568 (Grigore T. Popa University of Medicine and Pharmacy), and 1,514 students (George Enescu National University of Arts) (National Council for the Financing of Higher Education, 2019). 


\section{Student Mobility - Attractiveness and Premise of Improving the City Image. Case Study: Alexandru Ioan Cuza University of Iași \\ Journal of Settlements and Spatial Planning, Special Issue, no. 7 (2021) 73-80 Territorial Identities and Heritage. Discourses and Practices}

Furthermore, Alexandru Ioan Cuza University cooperates with over 400 universities around the world, making it an accessible and internationally renowned institute of education (educations.com, 2018).

\section{LITERATURE REVIEW}

The urban image can be defined as a puzzle made of distinctive goods (Metaxas, 2002); in certain situations, it is possible to identify a predominant image powerful enough to collect all the senses and vibrations. Also, the urban image represents the perception of the current, present urban reality - the first reality (the objective one), practically a mental representation of it, a second reality (Neacşu, 2003) or a second city, one recognizable using social investigation.

The source of the image of a place, implicitly of a city, is represented by the identity of that place (Banini and Ilovan, 2021). Furthermore, the urban identity is a uniform set of features with the same meaning for every resident of an urban settlement; at a mental level,it is expressed through a symbol built in time by each generation that guarantees the continuity and unity of the life of that urban community.Because the image is an essential factor for the people who use the city (Kavaratzis, 2008), the latter is forced to rediscover its identity and to reconsider and adapt its offer of services to consumers' new requirements.

The urban image reflects all the malfunctions of the current organization of the city, and the population of the settlement becomes an important factor of promoting it: "the formation and perception of the urban image is a long and complex process which involves a set of other images/perceptions, more specific an a priori perception (a mental construction in the knowledge space of an individual, without him physically visiting that place), an in-situ perception (arriving at the destination and experiencing that place) and a posteriori perception - after consuming the experience of the specific elements of the visited place" (Di Marino, 2008, p. 4). At the end of the 1990s, Simon Anholt created a model including six essential factors in shaping a territorial image, configured by a hexagonal geometric figure (Fig. 1).

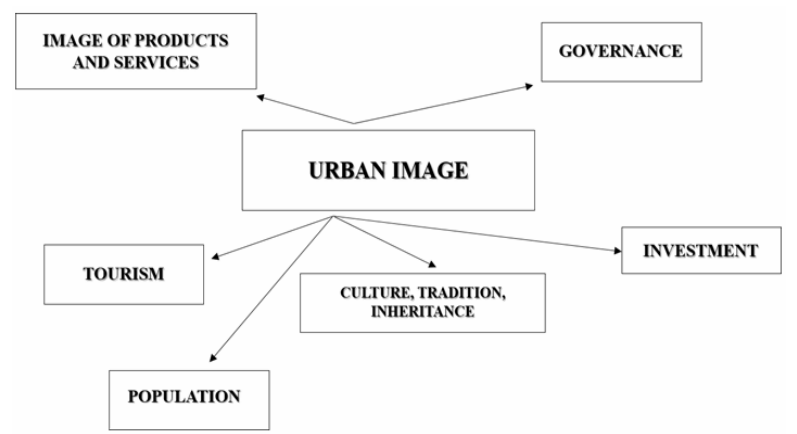

Fig. 1. Important factors in shaping the image of a place (source: Niculescu, Jinaru and Jinaru, 2017).
Although the concepts of educational tourism and specialized tourist products are worldwide relatively new, edu-travels are taking place for centuries. Being a product of the educational tourism industry, international university education is today a multi-billion-dollar business to numerous countries and to the global economy.

Worldwide, the highest level of edu-tourism development is in the countries with notorious higher education institutions: United Kingdom of Great Britain and Northern Ireland, Germany, United States of America, Canada and Switzerland. The educational tours are set in important schools, universities, institutes, in certain historical sites and well-known scholars' residences.

Educational tourism isa tourist activity carried out by people who spend at least one night in a hospitality facility and those who only participate in an excursion to the destination region and for who learning is the main or second part of their travel. The purpose of this short-term tourist program is learning, it focuses on formation of important qualities of individuals (general and specialised abilities) and the participants are mainly students.

This type of program offers to participants the opportunity to travel to a place as a group having the main purpose of engaging in a learning experience directly related to that region and evolves from a general motivation during the travel to learning as a main purpose of the trip.

Theactivities of edu-travels are various: knowing a school, culture, or tradition, learning a language, orparticipating inan academic or research program. In general, the educational tourism activities includeparticipation in conferences or seminars, study travels for adults, cross-border, or national university education (primarily) andtours of secondary school students and exchange programs (secondarily).

Educational tourism can serve to a variety of participants' interests and motivations: it satisfies the curiosity about other communities (also about their culture and language), it stimulates the interest in music or arts and inspires enthusiasm for natural environment and cultural and historic heritage; regardless of the topic, it includes an organized learning component. It becomes a powerful means in increasing social and economic capital and bringing learners and host communities in the centre of the global learning experience (Pittman, 2012).

It is focused on various students' needs (social, emotional, need for change and self-actualization, intellectual development, or exploration of the creative potential), it is expected that each participant can acquire skills and knowledge during edu-travels, and it is believed that edu-tours can improve the products of the local tourism. 
In the end, international - and national (inter - regional) - student mobility is important not only from an educational point of view but for tourism as well. Students often choose their universities not only because of the advantages of the universities but because of the tourist attractions of the university cities. On the other hand, educational mobility generates extra revenues for tourism destinations and consequently educational tourism should be regarded as an important element of destination management (Arva and Konyves, 2010).

\section{METHODOLOGY}

Our work objective is to analyse the evolution of Erasmus+ university mobility at Al. I. Cuza University (UAIC) Iași on both its components (Incoming and Outgoing), between 2013 and 2019, and to highlight, by the increasing number of students, the important role of these internships in the improvement of the city image as an attractive university centre. Due to the presence of significant cultural and historical institutions from Romania, of national personalities and to the increasing active participation of students in international internships, the city of Iași became a regional centre of educational polarization and attracted tourists from the native countries of the Erasmus+ participants.

We used in our research the empirical method (complex approach of higher education mobility and tourism) and the statistical analysis (detailed data of higher education tourism components: in this case increasing international university mobility in Iași and its potential role in the improvement of the image of Iaşi). To systematize the results, we used a detailed analysis of the educational tourism components at a global, regional, or local level and integrated partial information in a unitary representation, highlighting the complexity of the issue. The results were mapped to Philcarto and Adobe Illustrator (Table 2).

Table 2. Information used in our research.

\begin{tabular}{l|l}
$\begin{array}{c}\text { Bibliographical works } \\
\text { (booksand articles) } \\
\text { Mediated collection techniques }\end{array}$ & $\begin{array}{l}\text { Software (Philcarto, } \\
\text { Adobe Illustrator and } \\
\text { Microsoft Office) }\end{array}$ \\
\hline $\begin{array}{l}\text { Information related to: } \\
\text { - urban image; }\end{array}$ & $\begin{array}{l}\text { Descriptive maps and } \\
\text { - educational tourism in higher representing the } \\
\text { education; }\end{array}$ \\
$\begin{array}{l}\text { Mediated collection techniques: } \\
\text { distribution of variables } \\
\text { retained for analysis; } \\
\text { statistical data from the } \\
\text { International Relations Office of } \\
\text { students. }\end{array}$ \\
$\begin{array}{l}\text { Al. I. Cuza University: Erasmus } \\
\text { university mobility. }\end{array}$
\end{tabular}

\section{RESULTS AND DISCUSSION}

Approximately 35,000 Romanian students accessed Erasmus programs between 2007 and 2014 and the participation rates have been increasing every year. Most of them came from Al. I. Cuza University of Iași, Babeş-Bolyai of Cluj, University of Bucharest, followed by Transylvania University of Braşov and Polytechnic University of Timişoara (European Commission, 2017).

Al. I. Cuza University has a very important role in forming the image of Iași as an international university centre, the institution being on the first place in Romania regarding international academic exchanges of students, professors, and employees. Between 2016 and 2017, 863 internships took place through the Erasmus+ program with the participating countries, of which: 317 for students (study), 353 for students (practice), 133 for teachers (teaching) and 60 for administrative staff (training). Overall, the students and employees of the university visited a total of 190 universities and 117 institutions in 27 countries.

Data provided by the International Relations Office of the institution covers the period 2013/2019 and is related to the Erasmus+ international mobility (for study and internships) of students from Al. I. Cuza University, on both Incoming and Outgoing.

\subsection{Erasmus+ Outgoing Study}

Between 2013 and 2019 the number of Erasmus+ participants decreased from 356 participants in $2013 / 2014$ to only 261 in 2018/2019 (Fig. 2).

At the beginning of the program were accessed 12 countries and in 2019 were accessed another 20, with numerous fluctuations during the covered period: Lithuania appears as an option for students in $2018 / 2019$, to Liechtenstein there is no international mobility until 2016/2017, and to Slovenia and Sweden starting with the next year. A particular case is Switzerland, having only three students for 2013/2014.

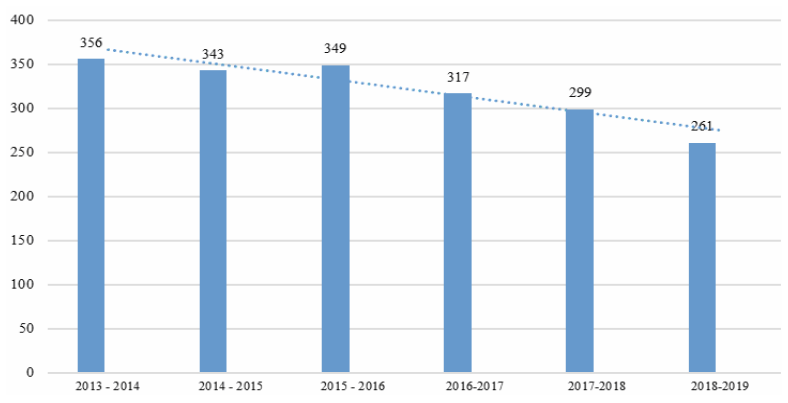

Fig. 2. The involution of the number of Erasmus+ Outgoing Study participants between 2013 and 2019 (source: UAIC Iaşi International Relations Office).

We distinguished six categories (Fig. 3):

- countries with high percentages of participants and decrease between 2013 and 2019: France (first place: from $23.03 \%$ in $2013 / 2014$ to $14.56 \%$ in 2018/2019) and Spain (about 10\% decrease);

- countries with high percentages of participants and increase between 2013 and 2019: Italy 


\section{Student Mobility - Attractiveness and Premise of Improving the City Image. Case Study: Alexandru Ioan Cuza University of Iași \\ Journal of Settlements and Spatial Planning, Special Issue, no. 7 (2021) 73-80 \\ Territorial Identities and Heritage. Discourses and Practices}

(first place: from $13.48 \%$ in $2013 / 2014$ to $14.18 \%$ in 2018/2019), Germany, Poland and Portugal;

- countries with low percentages and decrease between 2013 and 2019: Belgium, Norway, Turkey, and the U.K.;

- countries with low percentages but increase between 2013 and 2019: The Czech Republic, Greece, Finland, the Netherlands and Croatia;

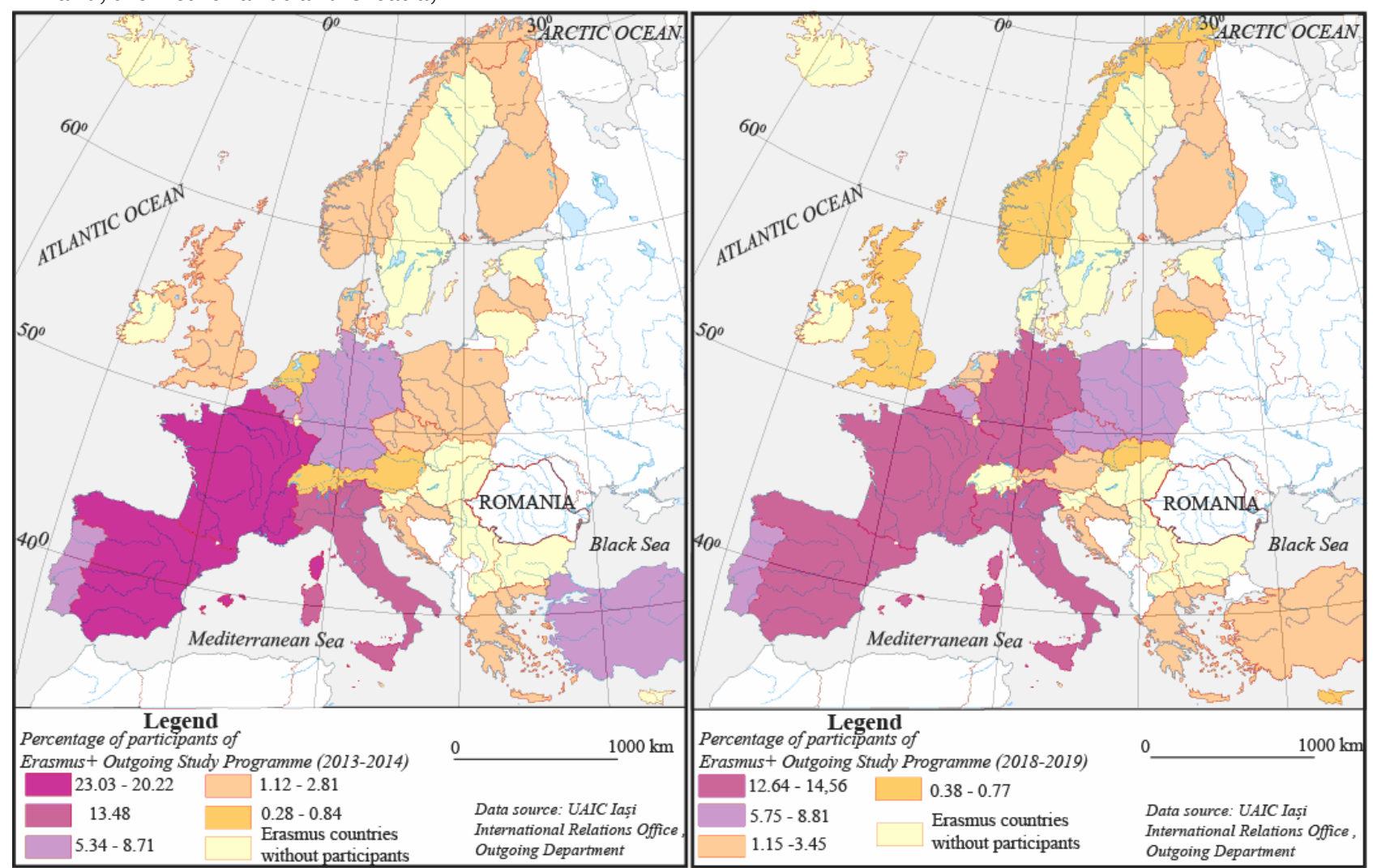

Fig. 3. Share of Erasmus+ Outgoing Study Program by destination country in 2013/2014 and 2018/2019.

\subsection{Erasmus+ Outgoing Practice}

Comparing with the Study component, the number of students had fluctuations and increased at the end of the period, from 307 participants in 2013/2014 to 335 participants in 2018/2019 (Fig. 4).

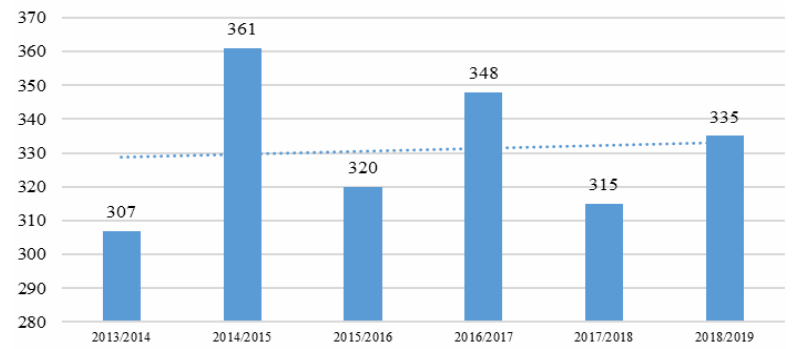

Fig. 4. The evolution of the number of Erasmus+ Outgoing Practice participants between 2013 and 2019 (source: UAIC Iași International Relations Office, Outgoing Department).

Two peaks of the values were in 2014/2015 and 2016/2017 (due to partnerships with new
- new study options for Romanian students between 2013 and 2019: Cyprus, Estonia, Lithuania, Slovakia and Slovenia; Liechtenstein and Denmark.
- countries that lost their Romanian students: 
Belgium, France, Portugal, Austria, the Czech Republic, Poland and Finland;

- countries with decrease but still keeping high percentages between 2013 and 2019: Greece (from $38.11 \%$ in $2013 / 2014$ to $30.15 \%$ in $2018 / 2019$ ), Italy (from $16.61 \%$ in $2013 / 2014$ to $12.84 \%$ in $2018 / 2019$ ) and Iceland;
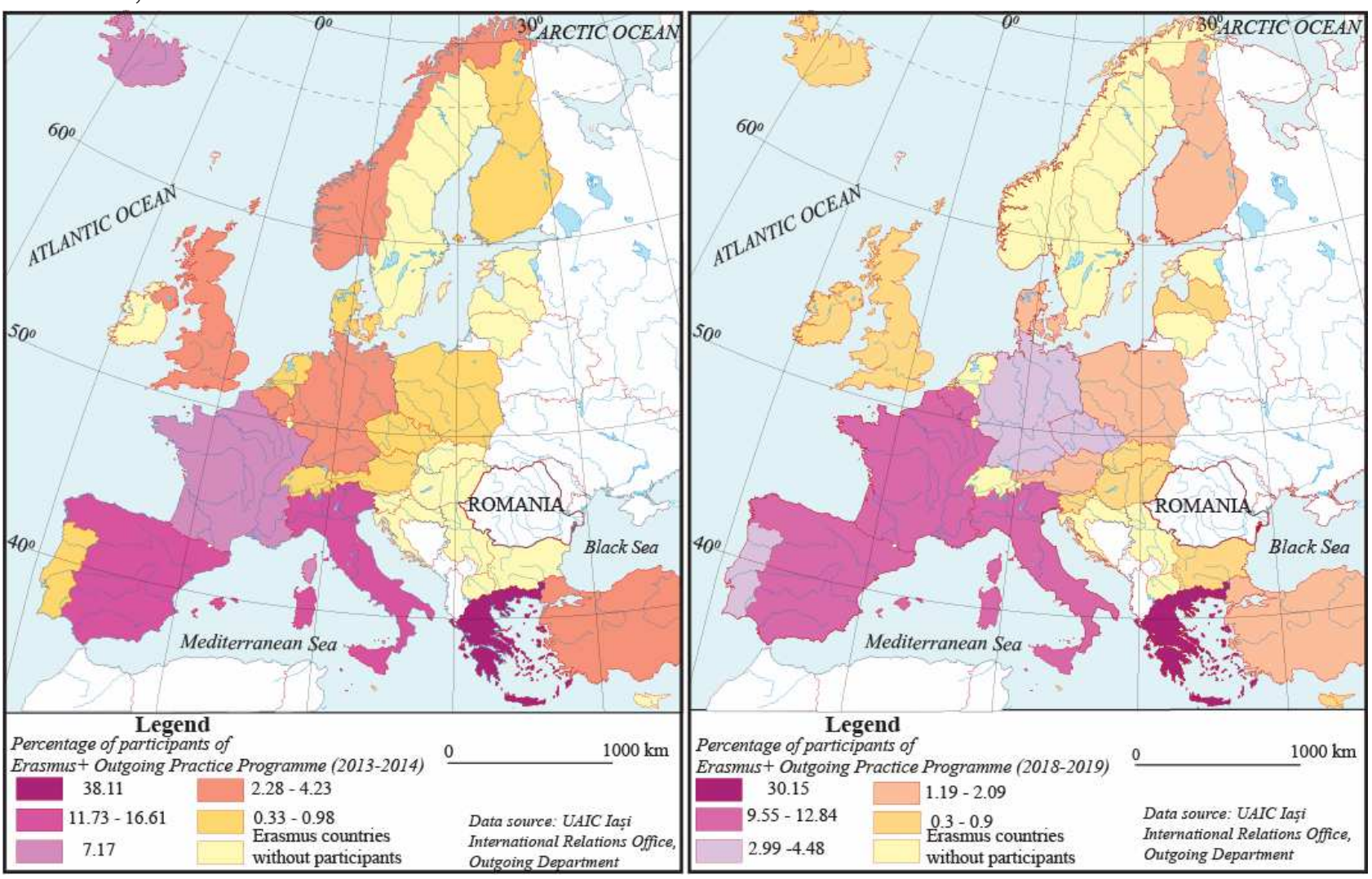

Fig. 5. Share of Erasmus+ Outgoing Practice Program by destination country in 2013/2014 and 2018/2019.

\subsection{Erasmus+ Incoming Study and Practice}

The Incoming component, Study and Practice are considered together, the number of participants for Practice being reduced between 2013 and 2019 (2016/2017: nine participants, four next year and 21 in 2018/2019). Therefore, Alexandru Ioan Cuza University is mainly a destination for Erasmus+ Incoming study internships (Fig. 6).

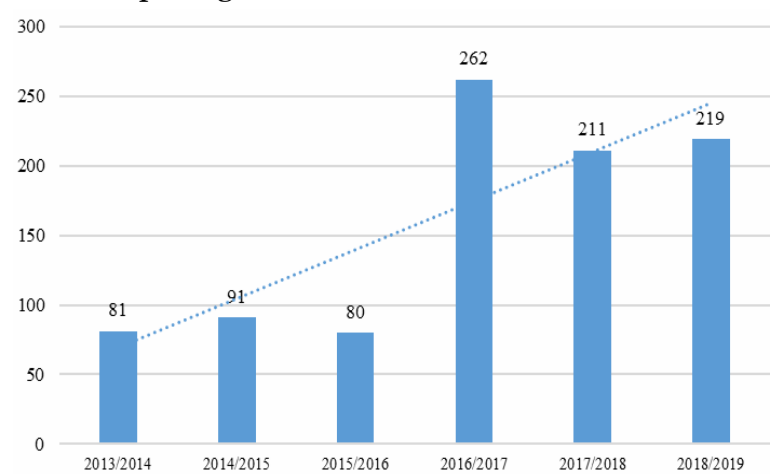

Fig. 6. The evolution of the number of Erasmus+ Incoming Study and Practice participants between 2013 and 2019 (source: UAIC Iași International Relations Office).
- countries with decreases of the percentages between 2013 and 2019: Germany, the U.K. and Turkey; - new practice options for Romanian students between 2013 and 2019: Slovakia, Slovenia, Latvia, Cyprus and Hungary. 


\section{Student Mobility - Attractiveness and Premise of Improving the City Image. Case Study: Alexandru Ioan Cuza University of Iași \\ Journal of Settlements and Spatial Planning, Special Issue, no. 7 (2021) 73-80 Territorial Identities and Heritage. Discourses and Practices}

Similar to the Outgoing Practice component, the number of students who arrived in Romania overall increased, a significant growth being in 2016/2017, from 80 participants to 262 due to partnerships of the university with new countries for example (22 new ones, including Albania, Algeria, Bosnia and Herzegovina, Uzbekistan and Vietnam).

We distinguished four categories of countries (see Fig. 7):

- the predominant category: new countries from where students arrived at Alexandru Ioan Cuza University including from the Asian, African and even American continents: Egypt, Algeria, Morocco, Tunisia, Vietnam, Japan, Russia and the U.S.A.;

- countries with decrease but still keeping high percentages between 2013 and 2019: France (from $28.40 \%$ in $2013 / 2014$ to $25.11 \%$ in $2018 / 2019$ ) and Spain;

- countries with low percentages of the participants and decrease between 2013 and 2019: Germany, Latvia, Poland and Portugal;

- Turkey and Italy were also mentioned (usually countries with high percentages of the participants during the analysed period), having slight increases during the same period. Overall, the international Erasmus+ mobility increased during the respective period from 744 participants in 2013/2014 (the beginning of the Erasmus+ program) to 815 participants in the 2018/2019, with numerous fluctuations (as a result of new partnerships among countries) and a peak of values (927 participants) in 2016/2017.

Erasmus+ university mobility had an important impact on the image of the city of Iași: for example, in the hospitality industry, the appearance of international restaurants (with Italian, Mediterranean coast, Greek, French, Lebanese or South American dishes).

Furthermore, in April 2018, in Iași arrived 24,927 tourists (increase by $0.4 \%$ comparing with the same month of the previous year); $22.6 \%$ of the total number of arrivals were foreign tourists ( 5,623 people), comparing with 20.6\% (in April 2017); 79.4\% of foreign tourists came from European countries (BZI Iași, 2018).

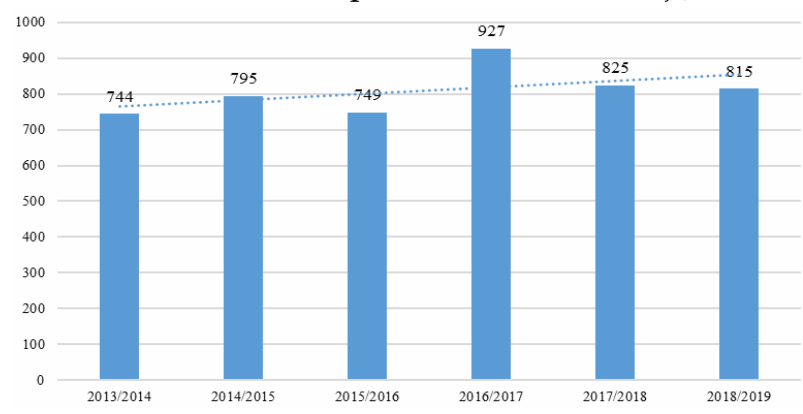

Fig. 8. The evolution of the number of Erasmus+ Incoming and Outgoing participants between 2013 and 2019 (source: UAIC Iași International Relations Office).
Therefore, the ascending trend of the Erasmus+ mobility between 2013 and 2019 in the city of Iaşi (Fig. 8) can improve the city image as an attractive university centre not only for the foreign students but also for the tourists from those students' native countries.

\section{CONCLUSIONS}

In the $21^{\text {st }}$ century, the urban image is becoming a reality essentialized at the level of every urban settlement. The construction of the urban image is a complex and long process based on flows between the city (with all its political, economic, social, cultural, religious, and natural dimensions) and anindividual (with all its attributes of interpretation and capitalization).

Numerous factors shape the image of Iași as a university centre but an essential one is the increasing number of students involved in Erasmus+ international internships. Between the academic years 2013/2014 and 2018/2019, the Erasmus+ international internships increased, and likewise the number of the participant countries. Excepting the Outgoing Study component, the number of Romanian students who went to study abroad and the number of foreign students who came to Romania for study and practice increased, the participation exceeding the European continent (African, Asian and North American countries). From this point of view, the university centre of Iași can be regarded both as a provider and as a receiver in university mobility, similar to states well-knownfor an active involvement in Erasmus+ programs (for example the Mediterranean countries).

Our study focused on the quantitative dimension of Erasmus+ mobility, highlighting the important role of foreign students who arrive in Iași in the improvement of the image of Iași as a university centre. Future research should consider the qualitative dimension of the phenomenon: the analysis of the Erasmus+ experience by applying a questionnaire to Alexandru Ioan Cuza University students in order toidentify the main directives of students' tourist behaviour in their chosen university centre and the impact of the internship on their professional and personal life.

\section{REFERENCES}

Alexandru Ioan Cuza University (2020), About Iași. URL: https://www.uaic.ro/iasi/. Accessed on 7.01.2021.

Arva L., Konyves E. (2010), Educational tourism and its effects on regional economy and destination management. In: Clarke A. (ed.), Constructing Central Europe. Tourism Competitiveness. University Press, Veszprem, 283-298. 
Banini T., Ilovan O.-R. (2021), Conclusions: towards a new agenda for place/territorial identity research. In: Banini T., Ilovan O.-R. (eds.), Representing Place and Territorial Identities in Europe. GeoJournal Library, vol. 127. Springer, Cham, 251-265, https://doi.org/10. 1007/978-3-030-66766-5_17.

Berna A., Dürdane B. J. (2014), Erasmus student mobility: some good practices according to views of Ankara university exchange students. Journal of Education and Future, 5, 57-72.

BZI Iași (2018), The Number of Tourists in Iasi Increased. URL: https://www.bzi.ro/. Accessed on 17.03.2021.

Di Marino E. (2008), The strategic dimension of destination image. An analysis of the French Riviera image from the Italian tourists' perceptions. Ph.D. thesis, Napoli Federico II University, Italy.

Education.com (2018), Top 10 Universities in Romania.URL: https://www.educations.com/.Accessed on 17.03.2021.

European Commission (2017), Erasmus pentru România - experiențe, destinații și evoluții [Erasmus for Romania Experiences, Destinations and Evolutions]. URL: https://ec.europa.eu/romania/content/episodul_3_era smus_pentru_romania_ro. Accessed on 7.01.2021.

Kavaratzis M. (2008), From city marketing to city branding: an interdisciplinary analysis with reference to Amsterdam, Budapest and Athens. Ph.D. Thesis, University of Groningen, Groningen.

Kotler P. (1997), Managementul marketingului [Marketing Management]. Editura Teora, București. [Book in Romanian]. ISBN 973-601-365-0.

Kotler P., Haider D. H., Rein I. (2001), Marketingul locurilor [The Marketing of Places]. Editura Teora, București. [Book in Romanian]. ISBN 978-973-200-094-6.

Mazilescu C. A., Dolga L., Filipescu H., PopescuMitroi M. M. (2016), Erasmus Mobilities of Students and Academic Staff of the Politehnica University of Timişoara. Editura de Vest, Timișoara. ISBN 978-97336-0706-9.

Metaxas T. (2002), Place/City marketing as a tool for local economic development and city's competitiveness: a comparative evaluation of place marketing policies in
European Cities. EURA Conference, Torino, Italy. URL: http://www.3ekf.tuke.sk. Accessed on 7.01.2021.

National Council for the Financing of Higher Education (2019), Public Report 2019. URL: http://www.cnfis.ro/. Accessed on 7.01.2021.

Neacşu M. (2003), Imaginea urbană. O nouă dimensiune în organizarea spaţiului urban [The urban image. A new dimension in the organization of urban space]. The Romanian Economic Journal, VI(11-12), 55-62. [Paper in Romanian].

Niculescu G., Jinaru D., Jinaru A. (2017), Premises for the design of the tourism brand of locality Targu-Jiu. Annals of the Constantin Brâncuşi University of Târgu Jiu, Letter and Social Science Series, Supplement 3, 57-65.

Paftală T. M. (2013), Imaginea de marcă în cadrul concurenței interurbane. Cazul marilor orașe românești: Braşov, Cluj-Napoca, Constanța, Galați, Iași, Timișoara [Brand image in long-distance competition. The case of the big Romanian cities: Braşov, Bucharest, Cluj Napoca, Constanta, Galați, Iaşi, Timișoara]. Universitatea Alexandru Ioan Cuza, Iași. [Doctoral thesis in Romanian].

Pittman J. (2012), Educational tourism empowerment: implications for flexible learning and digital equity. Journal of Tourism \& Hospitality, 1(4). DOI: 10.4172/2167-0269.1000e119.

Răcășan B. S., Egresi I., Ilovan O.-R., Dulamă M. E. (2021), Fieldwork for students in tourism programmes: is it more tourism than learning? The European Proceedings of Social and Behavioural Sciences, 334-344. DOI: 10.15405/epsbs.2021. 03.02.35.

Rodriguez C., Bustillo R., Mariel P. (2011), The determinants of international student mobility flows. An empirical study on the Erasmus programme. Higher Education, 62(4), 413-430. DOI: 10.1007/s10734-0109396-5.

Trout J., Rivkin S. (2006), Diferențiază-te sau mori [Differentiate Yourself or Die]. Editura Brand builders, București. [Book in Romania. ISBN 973-87488-7-9.

Zară I., Rus C. (2000), Imaginea şi creatorii săi, Volumul 1 [The Image and Its Creators, Volume 1]. Editura Victor, București. [Book in Romanian]. ISBN 973-00219-6-5. 